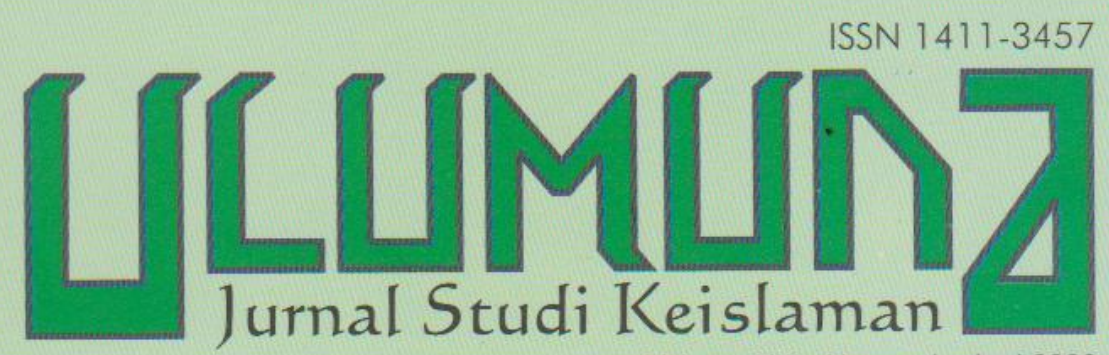

Volume XIII• Nomor $1 \cdot$ Juni 2009

TERAKREDITASI Berdasarkan SK Dirjen Dikti Depdiknas Nomor: 65a/DIKTV/Kep/2008

PEMIKIRAN FIQH DAN SPIRIT TRANSFORMASI SOSIAL Miftahul Huda

PERSPEKTIF MUHAMMAD SAT́D AL-ASYMÂWI TENTANG HISTORISITAS SYARI'AH Mutawalli

ASAS RETROAKTIF PADA KASUS PELANGgARAN HAM (PERSPEKTIF HUKUM ISLAM) Ikhwan

BMT DAN DEMOKRATISASI EKONOM: MEMBUMIKAN EKONOMI SYARIAH DI INDONESIA Lukman A - H Lkim

DINAMIKA PEMIKIRAN FIQH DALAM NU: ANALISIS ATAS NALAR FIQH POLA MAZHAB Ahmad Arifi

KOMPROMI DAN INTERSEKSIONALITAS GENDER DALAM PEMBERIAN MAHAR: TRADISI AMPA COI NDAI PADA SUKU MBOJO Atun Wardatun 


\section{PEDOMAN TRANSLITERASI}

\begin{tabular}{|c|c|c|c|}
\hline Arab & Latin & Arab & Latin \\
\hline 1 & $=$ & = & $=\mathrm{f}$ \\
\hline ب & $=$ & ق & $=\mathrm{q}$ \\
\hline$\dot{H}$ & ts & ك & $=\mathrm{k}$ \\
\hline 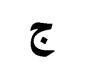 & $=$ & $J=$ & $=1$ \\
\hline$\tau$ & $=$ & b & $=\mathrm{m}$ \\
\hline$\dot{\tau}$ & $=\quad \mathbf{k h}$ & ن & $=\mathbf{n}$ \\
\hline$د$ & $=$ & و & $=\mathbf{w}$ \\
\hline$\dot{j}$ & $\mathrm{dz}$ & $\Delta$ & $=\mathbf{h}$ \\
\hline J & $=$ & $\varepsilon$ & $=$, \\
\hline j & $=$ & 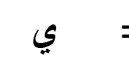 & $=\mathbf{y}$ \\
\hline س & $=$ & & \\
\hline ش ش & $\begin{array}{l}=\quad \text { sy } \\
=\quad \text { sh }\end{array}$ & \multicolumn{2}{|c|}{$\begin{array}{l}\text { Untuk Madd } \\
\text { dan Diftong }\end{array}$} \\
\hline ض & dl & $i$ & $=\hat{a}$ (a panjang) \\
\hline b & th & = & $=\hat{\mathbf{i}}(\mathbf{i}$ panjang $)$ \\
\hline ظ & $\mathbf{z h}$ & أو = & $=\hat{\mathbf{u}}$ (u panjang) \\
\hline$\varepsilon$ & $=$ & آو = & $=\mathbf{a w}$ \\
\hline$\dot{\varepsilon}$ & $=\mathbf{g h}$ & = آين & $=$ ay \\
\hline
\end{tabular}


TransLiterasi

ARTIKEL

Miftahul Huda

Mutawalli

Ikhwan

Kasjim Salenda

Hamid Fahmy

Rusli

Ahmad Arifi

Atun Wardatun
Pemikiran Fiqh

dan Spirit Transformasi Sosial $\bullet$ 1-22

Perspektif Muhammad Sa'îd al-Asymâwî

tentang Historisitas Syari'ah • 23-58

Asas Retroaktif

pada Kasus Pelanggaran HAM

(Perspektif Hukum Islam) • 59-80

Terorisme

dalam Perspektif Hukum Islam • 81-108

Genealogi

Liberalisasi Pemikiran Islam • 109-140

Kontroversi Akhbârî-Ushûlî

dalam Tradisi Pemikiran

Syı̀'ah Imâmiyyah • 141-168

Lukman Al-Hakim

BMT dan Demokratisasi Ekonomi:

Membumikan Ekonomi Syari'ah

di Indonesia • 169-188

Dinamika Pemikiran Fiqh dalam NU:

Analisis atas Nalar Fiqh

Pola Mazhab • 189-216.

Kompromi dan Interseksionalitas Gender dalam Pemberian Mahar: Tradisi Ampa

Co’i Ndai pada Suku Mbojo • 217-236.

\section{INDEKS}




\title{
DINAMIKA PEMIKIRAN FIQH DALAM NU (ANALISIS ATAS NALAR FIQH POLA MADZHAB)
}

\author{
Ahmad Arifi
}

\section{Abstract}

Figh as a product of thoughts always faces changes and developments. Similarly, NU's fiqh develops in line with NU communities' dynamics. Therefore, differences and diversities in NU fiqh must exist. In this context, the principle of al-muhâfazhah 'ala al-qadîm al-shâlih wa al-akhdz bi al-jadîd al-ashlah, which is attributed to NU, compromise two contradictory sides, that are classical heritage (al-turâts al-qadîm), which becomes a source and base for NU religiosity, and changing forces of eras and communities (al-tajdîd). This process, then, results in emergence of three groups in NU: the first accepts al-turâts as a final truth and a source for solving any problem in present communities, the second accepts al-turâts but it must be contextualized by considering communities' benefits, the third views al-turâts as out of date and irrelevant to the present contexts so that individual interpretation and judgment (ijtihad) is a must.

Keywords: Fiqh Madzhab, al-Turâts, al-Tajdîd, Pelapisan Sosial, Intelektual NU, Nalar Fiqh.

NAHDLATUL Ulama (NU) sebagai organisasi umat Islam Indonesia yang kelahirannya diprakarsai oleh para ulama berangkat dari persoalan fiqh, sehingga ia tidak bisa dilepaskan dari tradisi pemikiran fiqh, baik pada aspek kerangka teoritis (ushûul al-fiqh) maupun kaidah-kaidah fiqh (al-qawaid al-fiqhiyyah). ${ }^{1}$ Amaliah warga NU adalah amaliah yang didasarkan pada fiqh; atau dalam istilah Masdar Farid Mas'udi, fiqh sebagai

\footnotetext{
*Penulis adalah dosen tetap Fakultas Tarbiyah UIN Sunan Kalijaga Yogyakarta, Jl. Marsda Adisucipto Yogyakarta 55281. email: arifi_ahmad@yahoo.co.id

${ }^{1} \mathrm{M}$. Ali Haidar, Nabdlatul Ulama dan Islam di Indonesia Pendekatan Fiqh dalam Politik (Jakarta: PT Gramedia Pustaka Utama, 1994), 8.
} 
"panglima"-nya. ${ }^{2}$ Pemikiran fiqh dalam NU identik dengan fiqh madzhab, di mana setiap persoalan keagamaan (al-masâil aldiniyyah) yang muncul direspon dan dicari solusinya melalui forum bahtsul masail berdasarkan kitab-kitab fiqh madzhab empat yang diikuti (Hanafi, Maliki, Syafi'i, dan Hanbali).

Proses penetapan hukum (istinbâth al-abkâm) yang dikenal dalam Bahtsul Masail NU berkembang 3 (tiga) metode, ${ }^{3}$ yaitu metode qauly, yakni pengambilan keputusan hukum dengan mengutip teks/redaksi pendapat dari ulama madzhab yang tertulis di dalam kitab-kitab fiqh madzhab, metode ilhâqy atau ilhâq al-masâil binadhâirihâ, yakni dengan cara menganalogkan persoalan tersebut dengan masalah serupa yang sudah ada ketetapan hukumnya dalam kitab fiqh madzhab dan metode manbajy, yakni dengan melakukan istinbath hukum menurut cara (manhaj) yang telah ditempuh oleh imam madzhab yang dikenal dengan sebutan bermadzhab secara manhajy. Adanya tiga macam metode istinbâth ini menunjukkan, bahwa pemikiran fiqh "tradisi" pola madzhab dalam NU, betapapun ciri tradisional yang melekat pada NU, dinamika pemikiran fiqh tetap terjadi.

Mulai dekade 1990-an pemikiran fiqh dalam NU mengalami pergulatan intensif dalam forum bahtsul masail. Semakin banyaknya kaum intelektual NU dari perguruan tinggi yang terlibat di dalamnya, diskusi dan perdebatan di forum bahtsul masail semakin hidup. Demikian juga problem yang dihadapkan semakin kompleks menyangkut persoalan-persoalan kontemporer, sehingga mengundang perdebatan yang 'seru' manakala menghadapkan kutub al-madzâhib dengan problem kekinian. Pergulatan pun menyentuh aspek ontologi (hakekat fiqh), epistemologi (seperti dalil dan al-kutub al-mu'tabarah sebagai referensi (marâji), dan metodologi (istinbâth hukum).

${ }^{2}$ Dalam kritik Masdar terhadap tradisi ulama NU, pendekatan fiqh dalam NU ini sangat tekstualis, sehingga pemahamannya hitam putih (normatif). Lihat Ibid.

${ }^{3}$ Untuk penjelasan lebih lanjut tentang macam istinbâth hukum dalam Bahtsul Masail NU, lihat misalnya Ahmad Zahra, Tradisi Intelektual NU (Yogyakarta: LKiS, 2004), 167-70; KH. Husein Muhammad, “Tradisi Istinbath Hukum NU: Sebuah Kritik", dalam M. Imdadun Rahmat (ed.), Kritik Nalar Fiqh NU Transformasi Paradigma Babtsul Masail (Jakarta: Lakpesdam, 2002), 27-35. 
Adalah KH. MA. Sahal Mahfudh dengan Fiqh Sosial-nya yang mengedepankan perlunya kontekstualisasi fiqh pola madzhab dengan mengacu pada maqâshid syarîah dan qawầid fiqhiyyah bepengaruh dalam pemikiran fiqh NU. Sosok lain yang muncul secara fenomenal adalah Masdar Farid Mas'udi, seorang kiai muda dengan pemikirannya yang kritis, dan berani dengan gugatannya terhadap pola bermadzhab yang dianut NU. Pemikirannya yang kritis dan substantif diekspresikan dalam Islam (Fiqh) Emansipatoris.

Pergulatan pemikiran dalam NU dengan ragam ekspresi pemikiran di atas tidak terlepas dari sikap ulama NU dalam memaknai adagium al-muhâfadhat 'alâ al-qadîm al-shâlih wa alakhdzu bi al-jadîd al-ashlah sebagai ruang dinamis NU. Adagium ini memposisikan NU pada dua kutub yang saling tarik-menarik. Satu sisi NU sebagai jam'iyyah diniyyah meneguhkan pola bermadzhab dengan memegangi warisan klasik (al-turâts alqadim), yakni kitab-kitab fiqh madzhab. Pada sisi yang lain, NU tidak bisa menghindar dari perubahan dan kemajuan hasil modernisasi, yakni karya-karya intelektual modern (Barat) sebagai al-turâts al-gharbî. ${ }^{4}$ Dengan kata lain, meminjam istilah Al-Jabiri, pergulatan pemikiran Islam (NU) berada pada sikap tarik-menarik antara warisan lama/klasik (al-turâts) dan modernitas (al-hadâtsah). ${ }^{5}$

Melihat kompleksitas wacana fiqh dalam NU dan problematika pola bermadzhabnya, maka kajian tentang dinamika pemikiran (nalar) fiqh dalam NU dengan analisis paradigma nalar fiqh "tradisi" pola madzhabnya menarik untuk dicermati. Ini didasai oleh beberapa hal. Pertama, keunikan

${ }^{4}$ Iistilah al-turâts al-qadîm dan al-turâts al-gharbî ini dimunculkan oleh Hassan Hanafi ketika mencermati pergulatan pemikiran umat Islam (Arab) yang terjadi pada saat ini (di era modern). Pemikiran Islam berada pada tarik-menarik antara dua pengaruh warisan intelektual, yaitu al-turâts al-qadîm sebagai warisan Islam dan al-turâts al-gharbî sebagai warisan Barat; keduanya mempengaruhi pemikiran (intelektual) umat Islam. Lihat Hassan Hanafi, alTurâts wa al-Tajdîd Manqifunâ Min al-Turâts al-Qadîm; dan al-Turâts wa al-Tajdîd Mauqifunâ Min al-Turâts al-Gharbî Muqaddimah fî 'Ilm al-Istighrab (t. tp. : Dar alFaniyyah, t. t. ), 9-11.

5Lihat misalnya Muhammad 'Abid al-Jabiri, al-Turâts wa al-Hadâtsah Dirâsat wa Munâqasât (t. tp. : al-Markaz al-Tsaqafi al-'Arabi, t. t. ). 
karakteristik keagamaan NU dengan ciri tradisionalisnya yang berakar dari ideologi pola bermadzhab 'ala Ahlussunnah wal Jamaah ternyata membuka peluang terjadinya dinamika dan pergulatan pemikiran, khususnya pemikiran fiqhnya yang masih kurang mendapat perhatian, baik oleh peneliti dari NU sendiri maupun peneliti dari luar NU. Kedua, terjadinya pergulatan pemikiran fiqh yang berkembang di dalam NU mulai dekade 1990-an sampai sekarang ini besar pengaruhnya bagi pengembangan pemikiran fiqh "tradisi" pola madzhab ke depan sehingga melahirkan ragam corak nalar fiqh NU. Dan ketiga, bahwa NU konsisten dengan adagiumnya yang dipegangi selama ini, yaitu al-mubâfazhah 'alâ al-qadîm al-shâlih wa al-akhd₹ bi al-jadîd al-ashla $\underline{h}$, dengan menerapkannya pada metode qauly sampai manhajy, sehingga ruang dialog pemikiran akan selalu terbuka.

Untuk itu tulisan ini berupaya untuk mengungkap aspek dinamika pemikran fikih NU dengan corak nalar fikih yang berkembang di dalamnya.

\section{Dialektisme-Historis al-Turâts Wa al-Tajdîd Sebagai Pertautan Dinamis NU}

Masyarakat dalam perspektif sosiologisnya adalah suatu komunitas atau kelompok orang yang pada suatu saat akan mengalami perubahan. Tidak ada di dunia ini sebuah masyarakat yang tidak berubah. Perubahan masyarakat (perubahan sosial) dalam perspektif sosiologis adalah segala perubahan pada lembaga-lembaga kemasyarakatan di dalam suatu masyarakat yang mempengaruhi sitem sosialnya, termasuk di dalamnya nilainilai, sikap-sikap dan pola perikelakuan di antara kelompokkelompok dalam masyarakat itu. 6 Dengan berubahnya masyarakat, maka akan diikuti pula oleh perubahan nilai yang ada dalam masyarakat itu. Dalam konteks NU, Paul Doyle Johnson, sebagaimana dikutip Lukman Hakim, menyatakan bahwa ia akan mengalami perkembangan dan perubahan, seiring dengan perkembangan dan perubahan situasi, masa, dan konteks

'Soerjono Soekanto, Sosiologi Suatu Pengantar (Jakarta: Yayasan Penerbit FE UI, 1971), 237. Bandingkan dengan Selo Soemardjan dan Soelaiman Soemardi, Setangkai Bunga Sosiologi (Jakarta: Lembaga Penerbit FE UI, 1974), 491. 
sosialnya (termasuk menyangkut nilai-nilai yang berlaku di lingkungan internalnya, seperti ideologi bermadzhab sebagai sebuah nilai bagi masyarakat NU). Ia bergerak subjektif mengikuti dinamika makna subjektif individual, yakni mengikuti motif-motif, nilai-nilai tradisi dan ideologi yang mendasarinya. Kongkritnya, studi hubungan doktrin pola bermadzhab NU memotivasi warga NU dalam pola berfikir dan berperilaku (sosial, ekonomi, politik, dan budaya). ${ }^{7}$

Secara teoritis, perubahan nilai dalam masyarakat dapat dipengaruhi oleh beberapa faktor determinan, seperti tension (ketegangan) internal, ${ }^{8}$ tuntutan modernisasi, demokrasi, kontak dengan budaya luar, perkembangan iptek, munculnya sikap terbuka, toleransi dan lain-lain. ${ }^{9}$ Dalam perspektif sosiologis, perubahan yang terjadi dalam sebuah masyarakat setidaknya mencakup tiga dimensi, yaitu dimensi struktural, dimensi kultural dan dimensi interaksional. ${ }^{10}$ Terutama perubahan dalam dimensi kultural mengacu kepada perubahan kebudayaan dalam masyarakat, seperti adanya penemuan (discovery) dalam berpikir, pembaharuan hasil (invention) teknologi, kontak dengan kebudayaan lain yang menyebabkan terjadinya difusi dan peminjaman kebudayaan.

Permasalahan utama tentang pergulatan pemikiran fiqh dalam NU perlu dilihat pada kerangka pemikiran yang mendasarinya, yaitu pola bermadzhab yang dianut NU dalam mempertahankan warisan klasik sebagai sumber keberagamaan

${ }^{7}$ Lukman Hakim, Perlawanan Islam Kultural (Surabaya: Pustaka Eureka, 2004), 12.

${ }^{8}$ H. A. R. Gibb, Modern Trend in Islam (New York: Octagon Books, 1978), 17.

9Soeyono Soekanto, Sosiologi Suatu Pengantar (Jakarta: Raja Grafindo, 1999), 363-64. Dalam teori perubahan sosial, ada tiga penyebab utama (faktor determinan) terjadinya perubahan sosial, yaitu: (a) faktor biologis (terutama faktor demografis) seperti pertambahan penduduk dan migrasi, (b) faktor kebudayaan, yang meliputi sistem nilai, kepercayaan, morma, aturan, kebiasaan, dan pendidikan, (c) faktor teknologi,_dengan berbagai penemuan dan inovasi baru di bidang teknologi. Sudharto $\mathrm{Ph}$, "Penelaahan Teori tentang Perubahan Sosial", Muhammad Rusli Karim (ed. ), Seluk Beluk Perubahan Sosial (Surabaya: Usaha Nasional, 1982), 48-50 dan 66.

${ }^{10}$ Lihat Himes J. S. dan Moore, Study of Sociology (Atlanta: Scott Foresman, 1968), 430. 
di satu sisi dan realitas konteks sosial, yakni perubahan zaman dan tuntutan kebutuhan masyarakat di sisi lain. Pola bermadzhab melahirkan sikap tradisionalisme, dan perubahan situasi dan konteks sosial menuntut perlunya penyesuaian (perubahan) dan interpretasi baru atas tradisi yang melahirkan pembaruan. Dalam istilah Hassan Hanafi, antara tradisi dan pembaruan (al-turâts wa al-tajdîd) selalu terjadi pertautan dialektis secara dialogis-interaktif dan perlu diapresiasi.

Untuk melihat pergulatan pemikiran fiqh di kalangan ulama $\mathrm{NU}$, tepat kiranya mengadopsi teori Hassan Hanafi tentang alturâts wa al-tajdîd, berkenaan dengan sikap umat Islam (Arab) terhadap warisan klasik dan pembaruan pemikiran. Teori Hanafi ini berupaya untuk merekonstruksi bangunan pemikiran Islam (Arab), yang dalam sejarahnya, diwarnai oleh dua masalah mendasar, yakni warisan keilmuan klasik (al-turâts) di satu pihak, dan tuntutan keinginan untuk melakukan pembaruan (al-tajdîd) di pihak lain. Upaya (proyek) besar Hassan Hanafi ini diawali dengan mengemukakan sikap umat Islam (bangsa Arab) terhadap al-turâts al-qadîm di satu sisi, dan sikap mereka terhadap pemikiran (karya-karya ilmiah) para ilmuwan modern (Barat) yang disebut sebagai al-turâts al-gharbî. Dalam konteks kajian ini perlu dianalisis tentang sikap ulama NU terhadap warisan ulama klasik (al-kutub al-madzâhib) sebagai al-turâts al-qadîm dan karyakarya (pemikiran) intelektual modern (Barat dan Muslim di Barat) sebagai al-turats al-gharbi, yang melahirkan paradigma figh yang beragam.

Hassan Hanafi dalam mengkritisi sikap umat Islam terhadap at-turâts dan al-tajdîd didasarkan oleh asumsi, bahwa sebuah ilmu pegetahuan akan selalu berkembang dinamis dan mengalami perubahan dari zaman ke zaman. Sikap kita (umat Islam) akan selalu dihadapkan pada dua kepentingan yang saling tarikmenarik. Kita tidak bisa menutup mata dari hasil karya generasi terdahulu (periode klasik) yang telah menghasilkan sejumlah mahakarya ilmiah dalam berbagai bidang keilmuan.

Hanafi melihat Arab (umat Islam) saat ini diluberi oleh nilainilai "warisan" masa lalu. Institusi dan struktur pemikiran masyarakatnya merupakan perwujudan "warisan" itu. Menurutnya, "warisan" (al-turâts) tidak semata-mata manuskrip 
atau buku-buku yang sampai pada kita sekarang, tetapi seluruh interpretasi yang dilakukan oleh setiap generasi masa lalu dalam merespons kebutuhan-kebutuhannya. Dia meyakini bahwa tradisi tidak memiliki kebenaran yang abadi dan juga bukan doktrin yang tidak dapat salah, tetapi ia merupakan realisasi spesifik dari banyak keyakinan dan sikap tertentu di bawah kondisi historis tertentu pula. Bagi Hanafi, "warisan" bukan tumpukan material yang tersimpan dalam perpustakaan atau museum, dan bukan pula suatu entitas teoritis konseptual yang terlepas dari realitas historis, tetapi "warisan" merupakan penyimpanan pengaruh psikologis dari masa lalu yang telah hidup dalam masyarakat Arab dan membentuk bagian realitas Arab. ${ }^{11}$ Warisan itu sendiri sebenarnya tidak bernilai, kecuali jika ia dapat menjadi sarana yang dapat memberikan sebuah teori aksi bangsa Arab (umat Islam) dalam merekonstruksi manusia dalam hubungannya dengan Tuhan.

Aspek "warisan" itulah yang menginspirasi Hanafi untuk mengkaji tradisi, yakni kekuatan-kekuatan psikologisnya untuk mempengaruhi kesadaran dan perilaku masyarakat dalam aras, bukan untuk mempertahankannya, tetapi dalam rangka mengkaji saat sekarang melalui tradisi dan mengidentifikasi elemen-elemen negatif berupa kelemahan dan kemundurannya. Pengkajian tradisi digunakan dalam rangka menyingkirkan elemen kelemahan dan kemunduran untuk mengukuhkan elemenelemen positif berupa kekuatan dan "otentisitas" yang ada di dalamnya dan kemudian menjadikannya sebagai dasar kebangkitan Arab kontemporer menuju perubahan dan kemajuan. ${ }^{12}$

Hanafi berusaha menawarkan agar umat Islam memikirkan kembali seluruh persoalan mendasar yang muncul di masa lalu yang menjadi warisan Islam kontemporer dan kemudian menyeleksi seluruh solusi yang valid dan memungkinkan sesuai dengan kebutuhan era sekarang. Dia tidak setuju dengan kaum tradisionalis yang meyakini bahwa warisan (tradisi) telah menyediakan seluruh jawaban yang benar (dan komplit) untuk saat ini dan selamanya. Dia juga tidak setuju dengan kaum

${ }^{11}$ Ibid., 12-13.

12Ibid., 16-17. 
modernis yang mengabaikan "warisan" karena tenggelam dalam program-program modernisasi di berbagai bidang, membangun sesuatu yang baru di samping yang lama. Demikian juga, dia tidak setuju terhadap mereka yang berusaha menggabungkan warisan dengan modernitas, atau mereka yang menggabungkan modernitas dengan "warisan" secara "eklektik". Eklektisisme berusaha memiliki elemen-elemen dari salah satu atau yang lainnya, disertai dengan prasangka berlebihan tanpa adanya pandangan terhadap struktur logis totalitas, dan keberadaannya. Padahal "warisan" terus hidup dalam masyarakat yang dipenuhi dengan muatan-muatan psikologis yang kompleks akibat pengaruh masa lalu. ${ }^{13}$

Teori dialektisme-historis model Hanafi dalam al-turâts wa altajdìdnya menurut penulis tepat digunakan untuk melihat dinamika pemikiran fiqh NU, mengingat dinamika pemikiran fiqh NU mengikuti proses dialektis jalannya perkembangan masyarakat, adanya kekuatan-kekuatan sosial (intelektual) yang saling bertentangan dan mengikuti proses dialektis, ialah tesisantitesis-sintesis, dengan mengacu adagium "pelestarian turats (al-mubâfazhah) dan inovasi (al-akhdž) di atas.

Hanafi merumuskan kerangka teoritiknya secara skematik sebagai berikut:

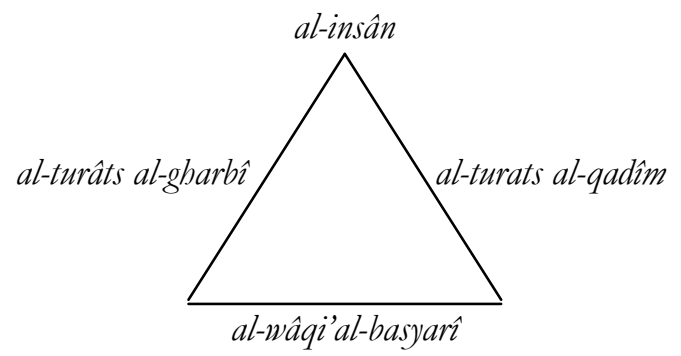

Dapat dijelaskan di sini, bahwa al-insan dimaksud dalam konteks penelitian ini adalah ulama NU sebagai subjeknya; $A$ turâts al-qadîm adalah kitab-kitab fiqh madzhab; Al-turâts al-gharbî dimaksudkan sebagai karya-karya keilmuan Barat (termasuk di dalamnya pemikiran-pemikiran intelektual Muslim yang dipengaruhi oleh Barat); dan al-wâqi' al-basyarî adalah masâil al-

13Ibid., 23-9. 
diniyyah wa al-ijtimâiyyah, yang menjadi fokus pembahasan dalam fiqh.

Bertolak dari tesis Hanafi di atas, maka turâts dan tajdîd (antara konservasi/tradisi dan inovasi/pembaruan) selalu berdialog secara terus-menerus. Dalam perspektif sosiologis, kaum nabdliyyin (khususnya ulama NU) akan dihadapkan pada dialektika antara sikap tradisionalitas dan tantangan modernitas. Namun demikian, terjadinya pergulatan pemikiran (figh) dalam NU, ciri tradisionalitas NU ternyata mendorong adanya dinamika atau bahkan perubahan paradigma.

Teori dialektisme-historis Hanafi di atas (pertautan antara alturâts wa al-tajdîd) sangat relevan dengan semangat keberagamaan dan pemikiran NU sendiri, yang selama ini dipegangi oleh NU yang didasarkan kepada kaidah al-munâfazhatu 'alâ al-qadîm alshâlih wa al-akhdžn bi al-jadîd al-ashlab. Dalam implementasinya, secara ideal kaidah ini merupakan wujud rekonsiliasi dua kutub yang berlawanan, yakni warisan klasik (al-turâts al-qadîm) yang menjadi sumber dan dasar keberagamaan warga NU, dan tuntutan perubahan zaman dan masyarakatnya (al-tajdîd). Dengan kaidah ini, NU berusaha melakukan kompromi aspek konservasi terhadap warisan lama (al-muhafadhah 'alâ al-qadîm) dan upaya inovasi (pembaruan) dengan memanfaatkan hasil pemikiran modern (al-akhdz bi al-jadîd).

Dengan demikian, tradisionalisme menuntut perlunya dinamisme dan perubahan. Pengembangan pemikiran fiqh dalam NU oleh karenanya menjadi suatu kebutuhan. Pengembangan wawasan pemikiran keislaman menjadi keniscayaan (bahkan dalam hal yang lebih mendasar diperlukan adanya perubahan paradigma), tidak sekedar karena kelatahan, tetapi didorong oleh tuntutan zaman yang memang demikian adanya.

Jika dicermati lebih mendalam, terjadinya pergulatan pemikiran yang tajam di kalangan NU diakibatkan oleh dua hal. Pertama adalah semangat ideologi (tradisi Islam Sunni) yang dianut NU. Sosok yang merepresentasikan semangat di atas adalah Abdurrahman Wahid. Dinamika dan pergeseran pemikiran NU dibentuk oleh tradisi fiqh madzhab Syafi'i yang lebih toleran terhadap keragaman dibanding madzhab-madzhab 
lainnya. Hal ini juga diungkapkan oleh Mitsuo Nakamura, ${ }^{14}$ Martin van Bruinessen, dan Greg Barton, ${ }^{15}$ (ketiganya sebagai pemerhati NU). Dengan kata lain, karena ideologi "tradisionalis" itulah yang menjadikan pemikiran NU menjadi dinamis, progresif, bahkan liberal.

Kedua adalah respon dan ketidakpuasan di kalangan generasi muda NU atas sikap para generasi tua (para kiai) yang terlalu berorientasi pada pemikiran madzhab sehingga membentuk dan melestarikan status quo. Sebagai akibatnya, terjadilah stagnasi pemikiran dan tidak memberi ruang gerak yang lebih luas bagi pemikiran-pemikiran di luar madzhab empat yang dianut NU. Hal ini dirasakan oleh Masdar dan Ulil Absar dengan komunitas Islam Liberalnya.

Pergulatan pemikiran fiqh yang terjadi di kalangan ulama NU selama ini melahirkan dua arus kecenderungan besar, yaitu kelompok yang mempertahankan warisan lama (bermadzhab) yang menolak segala bentuk kemodernan. Kemudian muncul kelompok lain, yang kontra konservatisme madzhab sebagai kelompok modernis yang pro (menerima) warisan Barat (al-turâts al-gharbî).

\section{Pergulatan Turâts dan Tajdîd: Terbentuknya Polarisasi}

Penegasan pola bermadzhab yang diikuti oleh NU mengandung konsekwensi bahwa tradisi harus dipelihara dan dipertahankan. Sementara itu, fakta sejarah menunjukkan bahwa perubahan sosial menuntut perlunya perubahan di segala aspek kehidupan masyarakat. ${ }^{16}$ Tradisi akan selalu berhadapan dengan

${ }^{14}$ Nakamura menyimpulkan bahwa tradisionalitas NU ternyata dapat menimbulkan radikalisme politik. Hal ini membuktikan bahwa tradisionalitas tidak selamanya menjadikan kekakuan, kepicikan dan eksklusif, serta tidak toleran. Ia bisa menjadi radikal betul-betul karena tradisionalisme keagamaannya. Lihat Greg Fealy dan Greg Barton (ed. ), Tradisionalisme Radikal, ter. Ahmad Suaedy dkk. (Yogyakarta: LkiS, 1997), 61.

15Ibid., 138 dan seterusnya.

16Dalam perspektif sosiologis, perubahan dalam masyarakat mencakup tiga dimensi, yaitu dimensi struktural yang menyangkut perubahan dalam peran sosialnya, dimensi kultural yang mengacu pada perubahan kebudayaan, seperti perubahan dalam berfikir, kontak dengan kubudayaan lain, dan dimensi interaksional yang berkaitan dengan perubahan pada relasi 
perubahan situasi dan konteks sosialnya. Pada wilayah hukum (figh) pun tidak bisa menghindar dari keniscayaan terjadinya perubahan, seiring dengan terjadinya perubahan zaman dan masyarakatnya. Perubahan pemikiran fiqh menurut teori dialektisme-historis (sebuah teori perubahan sosial), mengikuti proses dialektis perkembangan masyarakat, yakni adanya kekuatan-kekuatan sosial yang saling bertentangan, berdialektis dari tesis, antitesis, dan sintesis. ${ }^{17}$ Berkaitan dengan hal itu, para ulama juga telah merumuskan suatu kaidah, "la yunkar taghayyur al-abkâm bi taghayyur al-zamân wa al-ahwâl." 18

Tuntutan perubahan dan pembaruan juga tidak bisa dihindari oleh ulama NU karena tuntutan zaman, situasi, dan masyarakat. Oleh sebab itu, fiqh pola madzhab harus berdialog dan berinteraksi dengan perubahan untuk mencapai harmoni pola hubungan antara warisan tradisi (al-turâts) dan pembaruan (altajdîd). Tarik-menarik antara sikap mempertahankan tradisi (status quo), sebagai konsekwensi bermadzhab dan upaya pembebasan kultur tradisi, menyebabkan terjadinya pergulatan pemikiran di kalangan ulama NU dan sekaligus dilema bagi pengembangan fiqh dalam NU.

Ulama NU dalam menyikapi warisan klasik (al-turâts) yang berupa kitab-kitab fiqh madzhab dan tuntutan pembaruan pemikiran fiqh (al-tajdîd) tersebut, terbagi dalam tiga kelompok. Pertama, kelompok yang menerima al-turâts sebagai suatu kebenaran yang final. Warisan ulama klasik itu menjadi sumber solusi bagi problem-problem masyarakat masa kini. Kedua, kelompok yang menerima al-turâts sebagai suatu kebenaran yang masih dapat digunakan sebagai solusi bagi problem-problem masyarkat masa kini, akan tetapi perlu dikontekstualisasikan

sosial, seperti intimitas, formal, dan perenggangan. Lihat Himes J. S. dan Moore, Study of Sociology (Atlanta: Scott Foresman, 1968), 430. Bandingkan dengan M. Munandar Sulaiman, Dinamika Maysarakat Transisi (Yogyakarta: Pustaka Pelajar, 1998), 115.

${ }^{17}$ Lihat Sartono Kartodirdjo, Pendekatan Ilmu Sosial dalam Metodologi Sejarah (Jakarta: Gramedia Pustaka Utama, 1993), 163.

${ }^{18} \mathrm{Ali}$ Ahmad al-Nadwi, al-Qawầid Fiqhiyyah Mafhûmuhâ, Nasy atuhâ, Tathammuruhâ, Dirâsatu Muallifatubâ, Adillatuhâ, Mubimmatuhâ, Tathbiqatubâ (Damaskus: Dar al-Qalam, 1991 M-1412 H), 25, 56, 123; Subhi Mahmassani, Falsafat al-Tasyri' al-Islâmy (Beirut:Dâr al-'Ilmi, 1961), 200-2. 
dengan mengacu kepada kemaslahatan masyarakat. Ketiga, kelompok yang memandang al-turâts sebagai sesuatu yang sudah out of date (ketinggalan zaman) dan telah kehilangan konteksnya, sehingga tidak perlu lagi dijadikan sebagai rujukan untuk menjawab berbagai persoalan kekinian yang semakin kompleks. Untuk itu, yang perlu dilakukan adalah berijtihad sendiri berdasarkan kemaslahatan umat.

Kelompok pertama menginginkan NU sebagai kekuatan potensial pembela madzhab dan menjadi tulang punggung untuk tetap mempertahankan al-turâts al-qadîm, yakni pemikiranpemikiran ulama madzhab yang telah teruji oleh sejarah dan tetap eksis sampai sekarang, sehingga mereka tidak perlu lagi melakukan perubahan. Konsekwensi pola bermadzhab mengharuskan mereka untuk mengikuti apa yang telah digariskan oleh ulama-ulama madzhab. Kelompok ini umumnya diikuti oleh para kiai "sepuh" hasil didikan pesantren salafiyah yang konservatif dan para kiai "biasa" (kiai pesantren dan kiai "kampong") yang madzhab oriented.

Kelompok kedua, ulama NU moderat, menghendaki perlunya penyesuaian-penyesuaian dan perubahan dalam memegangi tradisi bermadzhab. Apa-apa yang berasal dari warisan ulama madzhab, jika memang masih relevan, maka itu tetap bisa diikuti oleh masyarakat sekarang dengan cara dikontekstualisasikan. Akan tetapi jika dari warisan itu tidak relevan lagi dengan konteks sekarang, maka bisa menggunakan metodologi ulama madzhab dan menggunakan kaidah-kaidah ushuliyyah atau fiqhiyyah dengan mengacu kepada kemaslahatan umat. Kelompok ini diikuti oleh para kiai NU yang berpendidikan pesantren plus sarjana. Mereka menguasai ilmuilmu Islam klasik (khususnya fiqh dan ushul fiqh) dan memiliki wawasan keilmuan modern. Di antara mereka ini adalah $\mathrm{KH}$. Sahal Mahfudh, Dr. KH. Masyhuri Na'im, KH. Afifuddin Muhajir, M. Ag. , dan santri Ma’had Aly P. P. Salafiyah Syafi'iyah Sukorejo Situbondo.

Kelompok ketiga (para intelektual NU “progressif”), menghendaki perubahan secara radikal untuk membebaskan diri dari 'ketergantungan' tradisi bermadzhab, mengingat fiqh madzhab merupakan produk pemikiran manusia yang tidak 
memiliki sifat keabadian (relatif kebenarannya) yang dipengaruhi dan dibatasi oleh ruang, waktu dan kondisi kultur masyarakat tertentu. Untuk kepentingan pengembangan pemikiran fiqh dalam NU, mereka menyerukan perlunya perubahan cara pandang (paradigma berfikir) ulama NU, baik secara kultural maupun struktural. Pola bermadzhab, dalam hal ini, harus direkonstruksi sesuai dengan tuntutan perubahan dan kebutuhan masyarakat sekarang. Kelompok ini diikuti oleh sebagian kecil intelektual NU, kalangan muda NU yang berasal dari kampus yang berlatar pendidikan pesantren dan menerima pemikiranpemikiran Barat kontemporer, bahkan liberal. Dapat disebut di sini, misalnya K. H. Masdar F. Mas'udi, Ulil Abshar dkk.

Sikap para ulama (intelektual) NU terhadap dua hal ini (alturâts wa tajdîd) melahirkan perubahan berfikir yang kemudian melahirkan pelapisan sosial (stratifikasi) intelektual NU, terutama ketika mereka dihadapkan kepada pengambilan keputusan hukum dalam bahtsul masail.

Stratifikasi ulama NU ini dapat diilustrasikan dengan piramida sebagai berikut:

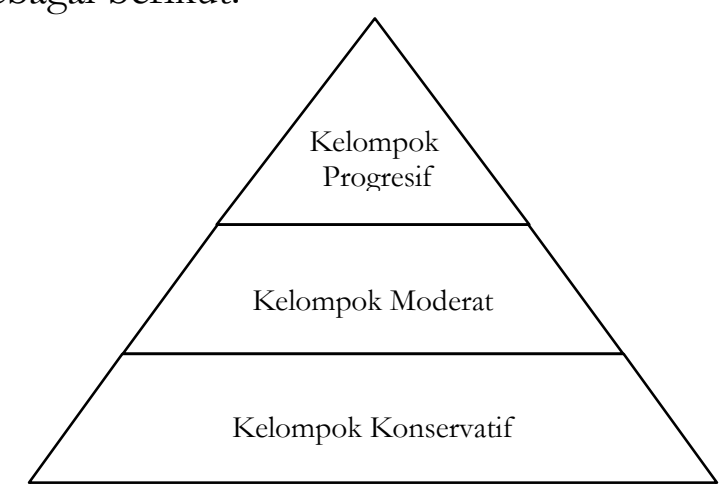

Gambar 1

Stratifikasi ulama NU berdasarkan sikap mereka terhadap al-turats wa al-tajdid.

Piramida di atas menunjukkan bahwa kelompok ulama NU konservatif masih sangat dominan mewarnai peta pemikirian fiqh NU yang mempertahankan status quo dalam pola madzhabnya. Sedangkan kelompok progresif menjadi bagian terkecil dalam komunitas ulama NU. 
Dalam hal interaksi sosial maupun struktural, ketiga kelompok sosial di atas terjadi pola hubungan yang unik. Pada suatu saat bisa terjadi hubungan yang harmonis, dan di saat yang lain bisa menjadi konflik, terutama antara kelompok pertama dan ketiga. Dalam hal relasi sosialnya, kelompok pertama (ulama NU tua) dan ketiga (kaum NU muda) terjadi interaksi yang positif dan harmonis, mereka saling memahami dan menghormati. Ulama NU tua menerima keberadaan kaum NU muda sebagai bagian dari komunitas keluarga besar NU. Demikian juga, kaum NU muda menaruh hormat kepada kaum tua (ulama senior).

Berbeda halnya pada saat dua kelompok tersebut (kaum NU tua dan kaum NU muda) berinteraksi (berdialog) dalam hal pemikiran keagamaan (figh misalnya), pola hubungan mereka terjadi ketegangan. Mereka menjadi berseberangan, berbeda satu dengan lainnya dan tidak ada titik temunya. Kaum tua dengan tegas menolak apa yang dilakukan oleh kaum muda dengan pemikiran-pemikiran progresif (liberal)-nya, seperti penggunaan hermeneutika dalam pemikiran Islam, liberalisme madzhab, dan isu-isu liberal lainnya. Demikian juga kaum NU muda menolak sikap status quo pemikiran kaum tua. Di sini tampak jelas terjadi perubahan pada dimensi interaksional, khususnya berkenaan dengan sikap mereka terhadap pola bermadzhab ketika merespons persoalan-persoalan keagamaan, baik secara perseorangan maupun dalam forum bahtsul masail.

Pola hubungan relasional tersebut dapat digambarkan sebagai berikut:

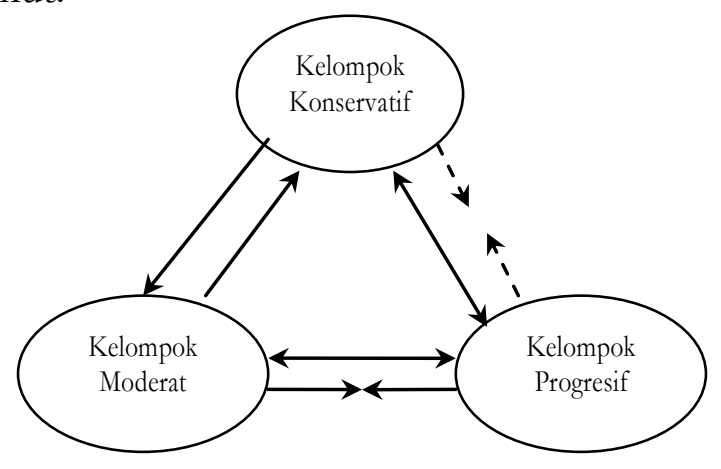

Gambar 2

Pola interaksi antar kelompok dalam komunitas ulama NU 
Pada skema di atas tergambar bahwa pola hubungan langsung maupun tidak langsung terjadi antara ketiga kelompok sosial ulama NU, dalam arti bahwa mereka berinteraksi satu sama lain, saling mengetahui posisi dan arah pemikirannya. Tetapi pada kasus yang lain, antara kaum tua dan kaum muda (progresif) berseberangan, tidak bisa ketemu pemikiran keduanya dalam hal pola madzhab.

\section{Aspek Dinamis dalam Tradisionalisme Fiqh Pola Mazhab}

Menarik untuk disermati apa yang dikatakan oleh K. H. Ma'ruf Amin (salah seorang Ketua PBNU dan pakar fiqh) berkenaan dengan fiqh tradisi pola madzhab yang dianut NU. Amin menjelaskan bahwa bermadzhab tidak berarti selalu statis dalam pemikiran fiqhnya. Dalam konteks mensikapi masalah alturâts wa al-tajdîd dalam pemikiran fiqh $\mathrm{NU}$, bermadzhab adalah sesuatu yang final bagi NU. Oleh karenanya, NU tidak akan menanggalkan tradisi bermadzhab. Namun demikian, bermadzhab tidak berarti menghalangi kita untuk melakukan perubahan, karena perubahan itu sendiri juga sesuatu yang "pasti" terjadi. 19 Dalam pemikiran fiqh, NU dengan pola madzhabnya akan selalu bersikap terbuka dengan perubahan, sehingga figh NU menjadi dinamis. Seperti dimaklumi bahwa alnushûsh al-syar'iyyah mutanâhiyah wa al-waqâi' ghairu mutanâhiyah. Hal ini sejalan dengan fikrah nabdliyyah, yang di dalamnya ada aspek tathawnuriyah (dinamis) sebagai ciri NU.

Lebih lanjut Amin menjelaskan, fiqh NU dengan pola madzhabnya tidak menutup kemungkinan terjadinya perubahan dan pembaruan, baik pada masalah isi (materi) maupun teknis metodologi (manhaj)-nya. Materi pembahasan fiqh dalam bahtsul masail dari waktu ke waktu mengalami perkembangan seiring dengan dinamika masyarakat. Sejak tahun 1992, ketika Munas Alim Ulama di Lampung dilaksanakan, pembahasan materi fiqh di dalam Bahtsul Masail diperluas. Sebelumnya hanya membahas masalah-masalah keagamaan yang bersifat kejadian aktual (almasâil al-dîniyyah al-waqi'iyyah), kemudian diangkat pula masalah-

${ }^{19}$ KH. Ma'ruf Amin, Wawancara, tanggal 28 Juli 2006. 
masalah yang bersifat tematik (al-masâil al-dîniyyah al-maudlûiyyah), seperti masalah HAM, Gender, Nasionalisme, dan Terorisme.

Demikian juga berkenaan dengan proses pengambilan keputusan hukum, Munas Lampung telah menetapkan langkahlangkah metodologis (istinbâth al-abkam) yang dikembangkan NU mencakup tiga macam, yaitu: (1) pola bermadzhab qauly (tekstual); (2) pola ilhâqy (ilhâq al-masâil bi nadhâirihâ); (3) cara taqrîr jama'i, yakni melakukan penetapan hukum dengan mengikuti manhaj istinbâth yang ditempuh oleh imam madzhab yang dinamakan metode manhajy .

Senada dengan Ma'ruf Amin, Sahal Mahfudh (Raîs 'Âmm) mengatakan bahwa bermadzhab yang diikuti NU tidak berarti taqlid yang statis. Di dalam bermadzhab terdapat ruh/semangat dinamis. Hal ini bisa dilihat dalam forum bahtsul masail, yang sangat menghargai adanya perbedaan pendapat. Bahkan, talfî $q$ dalam arti positif, yakni berpindah dari pendapat madzhab tertentu kepada pendapat madzhab yang lain dalam perkara hukum tertentu diperbolehkan. 20 Demikian juga diperkenankannya menggunakan referensi kitab-kitab ghayr mu'tabarah (di luar kutub al-madzâhib yang diakui) selama itu memiliki argumentasi yang jelas. Jadi, fiqh madzhab tidak harus diambil secara kaku (istilah Belanda: letterlijk), tetapi upaya kontekstualisasinya lebih penting.

Menurut Sahal, kontekstualisasi kitab kuning harus menjadi "tradisi baru" bagi ulama NU agar tidak terjebak oleh status quo dan belenggu kultural bermadzhab. Hal tersebut juga dicontohkan Imam Syafi'i yang melahirkan dua pendapatnya yang dikenal dengan Qaul Qadîm (saat beliau tinggal di Iraq, ketika madzhab rasional Hanafi berpengaruh), dan Qaul Jadîd (pendapatnya saat tinggal di Mesir). Ini menunjukkan bahwa konteks sosial akan mempengaruhi ketetapan hukum yang diambil. Oleh sebab itu, bermadzhab tetap menjadi pilihan bagi NU, akan tetapi yang lebih penting dari mengikuti madzhab adalah perlunya kontekstualisasi pemikiran madzhab dan menjadikannya sebagai "ruh" semangat bagi pengembangan pemikiran fiqh NU ke depan.

${ }^{20}$ KH. MA. Sahal Mahfudh, Wawancara, tanggal 20 Juli 2005. 
Sikap yang berbeda diambil oleh Masdar F. Mas'udi (intelektual/kiai progresif NU) ketika dihadapkan pada pertautan turâts dan tajdîd (warisan tradisi dan pembaruan) dalam konteks bermadzhab. Masdar memandang kitab-kitab fiqh madzhab memiliki konteks zaman dan sosialnya sendiri, sedangkan kita memiliki konteks zaman dan sosial sendiri yang tentunya berbeda. Karena itu, sikap kita terhadap turâts (warisan klasik) tidak serta merta menjadikan kita harus selamanya sama dengan mereka (generasi pendahulu kita). Dalam meresponss masalah dan mengambil solusinya, keputusan hukum yang kita ambil tidak harus sama, dengan mendasarkan pada pendapat-pendapat ulama masa lalu. Ketetapan hukum itu harus didasarkan pada kemaslahatan, yang memang menjadi tujuan diadakannya hukum. ${ }^{21}$ Ketetapan hukum yang terdapat dalam kitab-kitab fiqh madzhab mengandung maslahah bagi konteks zaman dan masyarakat pada waktu itu. Konteks zaman dan kemaslahatan kita sekarang tentunya berbeda dari kemaslahatan umat masa lalu. Oleh karena itu, bermadzhab dengan mengikuti qaul (pendapat) yang dibuat pada konteks zaman dan sosial yang telah lewat jauh dengan kita berarti kita telah terperangkap oleh hegemoni kultural.

Masdar menyadari adanya struktur tradisional, otoritarian, dan koersif dalam komunitas NU sekarang. Dominasi kiai tua di lembaga Syuriyah (yang membawahi Bahtsul Masail) dengan paradigma lama (tekstualis) yang melestarikan status quo, menjadikan wacana fiqh dalam NU terasa beku dan jumud. Orientasi bermadzhab menjadikan wacana Islam (fiqh) bersifat tekstualistik dan formalistik. Problem yang serius dalam wacana fiqh "tradisi" NU yang berorientasi pada madzhab adalah bahwa teks yang menjadi pijakan tidaklah teks primer (al-Qur'an dan alHadis), melainkan teks tertier (kitab-kitab fiqh madzhab) yang telah tersakralisasi. Standar kebenaran tidak dicari pada teks dengan otoritas tinggi seperti al-Qur'an, hadis, atau Madzhab Empat, melainkan pada otoritas ulama pada tingkatan pada ashhâb muttafaq 'alaihi wa al-Râfi'̌. ${ }^{22}$

${ }^{21}$ K. H. Masdar F. Mas'udi, Wawancara, tanggal 29 Juli 2006.

${ }^{22}$ Lihat Masdar F. Mas'udi, "Paradigma dan Metodologi Islam Emansipatoris", Pengantar Umum dalam Very Verdiansyah, Islam 
Untuk mencairkan kebekuan dan kejumudan tersebut, langkah yang harus ditempuh oleh kita (warga NU) adalah mengembalikan persoalan kepada asalnya, yakni dalam membuat ketetapan hukum atas berbagai persoalan yang muncul di masyarakat sekarang ini dengan mendasarkan kepada kemaslahatan sebagaimana yang ditunjukkan oleh nash. Dalam kaitan ini, kaidah yang diungkapkan Imam Syafi'i, "idzâ shabha al-

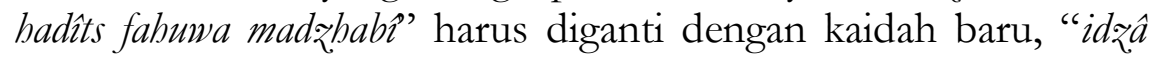
shabha al-mashlabat fahuwa madrhabì. ${ }^{23}$ Kaidah yang pertama (Imam Syafi'i) akan membuat kita terjebak pada tekstualisme dan sikap formalistik, sedangkan kaidah kedua akan mengarahkan kita pada sikap kritis dan kontekstualis. Yang harus diperhatikan adalah bahwa hukum (agama) itu diadakan untuk mewujudkan kemaslahatan manusia sehingga aturanaturannya pun harus selaras dengan kemaslahatan manusia. Oleh sebab itu, dalam rangka pengembangan fiqh NU harus mengacu pada kerangka maslahat ini. Kita tidak bisa menjadikan kitabkitab fiqh madzhab sebagai "nilai" yang harus dipatuhi; ia menjadi panglima bagi kita. Akan tetapi, kemaslahatan yang justru kita jadikan sebagai panglima dan sistem nilai yang mendasari bagi fiqh madzhab. Meninggalkan madzhab dan mengutamakan kemaslahatan adalah sikap yang seharusnya dilakukan oleh kita.

\section{Ragam Nalar Fiqh yang Berkembang di dalam NU}

\section{Nalar fiqh Formalistik-Tekstualis.}

Nalar fiqh ini memahami fiqh sebagai produk ijtihad ulama mujtahid di masa lalu yang sudah teruji validitas dan objektivitasnya. Fiqh hasil ijtihad tersebut dipandang layak untuk dijadikan acuan dan rujukan bagi kita (umat Islam) untuk meresponss persoalan-persoalan hukum yang muncul di masa sekarang. Mereka (para ulama mujtahid) telah memiliki peringkat

Emansipatoris: Menafsir Agama Untuk Praksis Pembebasan (Jakarta: P3M, 2004), xiv.

${ }^{23}$ Baca Masdar F. Mas'udi, "Meletakkan Kembali Maslahat sebagai Acuan Syari'at", Ulumul Qur'an: Jurnal Ilmu dan Kebudayaan, Vol. VI, No. 3 (1995), 97. 
sebagai mujtahid yang diakui oleh umat Islam sebagai ulama yang patut diikuti. Mengingat kemampuan ulama sekarang, yang sulit (tidak mungkin) mencapai derajat sebagaimana ulama mujtahid masa lalu (sebagai mujtahid), maka mengikuti pendapat mereka (bertaqlid) adalah satu-satunya jalan yang paling selamat dan aman. Bertaqlid merupakan kewajiban bagi umat Islam generasi setelah masa imam madzhab dalam pandangan madzhab Sunni. Dengan demikian, kita tidak perlu lagi "merekareka" atau berijtihad sendiri dalam meresponss berbagai masalah hukum yang muncul sekarang. Fiqh madzhab sebagai khazanah yurisprudensi yang kaya dengan keragaman pendapat (aqwa), dirasa sudah cukup dan masih relevan untuk menjawab persoalan di masa sekarang.

Produk fiqh nalar formalistik-tekstual hanya mengacu pada fiqh ulama madzhab yang bersifat reproduksi (copying), yakni mengambil jawaban secara "apa adanya" dari teks kitab fiqh madzhab, tanpa mengubah isi/bunyi teks. Fiqh ulama madzhab dalam hal ini adalah satu-satunya sumber referensi (marâji) bagi para ulama NU ketika merespons persoalan fiqh melalui Bahtsul Masail, terlepas dari sumber asalnya (al-Qur'an dan al-Hadis) dan juga maqâshid syarîah-nya (al-maslahab).

Tesis yang dibangun adalah, bahwa mempertahankan fiqh madzhab adalah sesuatu yang final, dan ini merupakan sebuah konsekuensi mengikuti pola bermadzhab. Adalah tidak benar jika menyatakan dirinya bermadzhab, tetapi dalam prakteknya tidak mengikuti aturan-aturan bermadzhab. Dengan demikian, NU sebagai kelompok muslim yang mengikuti madzhab, maka sudah sewajarnya mengikuti apa-apa yang telah dihasilkan dari ulama madzhab, dan menjadi kewajiban untuk mempertahankannya.

Dengan melihat paradigma di atas, kelemahan mendasar dari nalar fiqh formalistik-tekstual ini adalah bahwa para ulama NU tidak kreatif dalam memberikan jawaban atau pendapat hukumnya. Dalam beberapa kasus, menjadikan fiqh NU mengalami kebekuan, padahal fiqh itu sendiri bersifat dinamis 
mengikuti dinamika masyarakatnya, sebagaimana kaidah fiqh, bukm al-syai' yadûru ma'a atsaribi wujudan wa 'adaman. ${ }^{24}$

Kelompok ini bisa dikatakan sebagai kalangan konservatif madzhab (al-mubâfiz̧hîn). Kelompok ini memegangi doktrin madzhab dengan sangat kuat dan berupaya untuk mempertahankan status quo dengan berpegang erat pada pendapat madzhab. Bukti nyata kuatnya sikap konservatif tersebut adalah ditolaknya wacana "hermeneutik" dan pemikiran liberal sebagai suatu pendekatan hukum atau metode penafsiran untuk Bahtsul Masail pada Muktamar NU ke-31 di Asrama Haji Donohudan Boyolali tahun 2004.

Menurut analisis penulis, ada beberapa faktor (indikator) yang menyebabkan masih kuatnya pola nalar formalistik-tekstual ini, di antaranya sebagai berikut.

a. Para ulama (kiai) NU yang mengikuti ortodoksi madzhab adalah para kiai pesantren yang mengenyam pendidikan dari pesantren-pesatren salafiyah an sich. Kitab-kitab yang menjadi rujukan mereka adalah kitab-kitab fiqh yang dipelajarinya selama di pesantren, yang kesemuanya bermadzhab Syafi'iyah. Para ulama NU yang memiliki mindset demikian ini umumnya tinggal di kampung (pedesaan) dan memiliki pengaruh kuat di masyarakatnya (pesantren) dan sekitarnya. Sebagian mereka juga menjadi anggota Syuriyah NU di tingkat cabang, atau wilayah. Meski juga ada yang berada di tingkat pengurus pusat (Syuriyah PBNU). Beberapa kiai senior NU seperti KH. Masduki, KH. Syadid (Probolinggo, Jawa Timur), KH. Zainal Abidin (Krapyak, Yogyakarta) adalah sosok yang cukup vokal dengan pola ini.

b. Militansi pemikiran mereka dalam memegangi ideologi bermadzhab qauly adalah sebagai akibat dari kurangnya apresiasi mereka terhadap ilmu ushul fiqh, terutama ketika merespons masalah fiqh, juga tidak menggunakan qawâid fiqhiyyah, maupun fiqh muqâran (fiqh lintas madzhab).

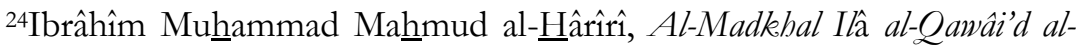
Fiqbiyyah al-Kulliyyah: Ta'rifubâ - Nasy'atubâ - Tathawnurubâ - Syar'iyyatubâ Tashnîfuhâ - wa Qawâidu Ushûliyyah Lahâ Shillatun Biha (Amman: Dâr 'Ammâr, 1998), 178 dan 190. 
c. Terbatasnya pengalaman dan keterlibatan mereka dalam mengikuti forum-forum ilmiah atau Bahtsul Masail tentang berbagai isu fiqh kontemporer, terutama yang melibatkan para ulama plus (alumni pesantren dan sarjana) yang menguasai disiplin ilmu secara multidisipliner dan wawasan multikultur.

\section{Nalar Fiqh Sosial-Kontekstual.}

Nalar fiqh sosial ini memandang fiqh sebagaimana pengertian fiqh yang didefinisikan oleh para ulama ushul, yakni sebagai proses istinbatth atau ijtihad hukum. Produk pemikiran fiqh ulama mujtahid (imam madzhab) masa lalu sampai sekarang tetap bersifat “tentatif” kebenarannya (z̧anny al-dalâlah), bukan sebagai sesuatu yang bersifat absolut dan final. Kebenaran dari suatu hasil ijtihad terbuka untuk dikoreksi. Oleh sebab itu, fiqh madzhab dalam pandangan kelompok ini memiliki dua wajah sebagai berikut.

a. Sebagai produk ijtihad, ia (fiqh madzhab) bisa benar dan bisa jadi salah. Kebenarannya bisa dijadikan sandaran penyelesaian bagi persoalan hukum yang timbul saat sekarang, jika ia memang masih relevan atau sesuai dengan konteks sosial masyarakat sekarang. Dalam hal ini, merujuk pada pendapat ulama masa lalu (bertaqlid) tidak jadi soal, selama taqlid tersebut didasarkan pada pertimbangan dan analisis yang argumentatif. Hal ini berarti kita bertaqlid dengan benar-benar memahami alur pemikiran (metodologi) yang ditempuh oleh ulama tersebut dan mengetahui akar masalahnya. Namun demikian, menggunakan fiqh madzhab sebagai sandaran (referensi) bagi persoalan kekinian perlu kontekstualisasi, agar muatan dalam kitab fiqh madzhab memiliki kontekstualitas dan relevansinya dengan konteks masa kini.

b. Sebagai hasil ijtihad, ketentuan-ketentuan hukum yang ada dalam fiqh madzhab bisa jadi tidak relevan lagi dengan konteks sosial masyarakat sekarang. Oleh karena itu, pendapat hukum (qaul) yang dihasilkan tidak harus dilestarikan atau diikuti seperti ada adanya. Sebagai konsekwensinya, kita (para ulama) sekarang perlu melakukan 
istinbâth (ijtihad meski dalam arti yang terbatas), baik secara perseorangan maupun secara kolektif. Metodologi (manhaj) dari imam madzhab tetap bisa dipergunakan untuk menjawab persoalan sekarang, karena metodologinya memang masih up to date dan telah teruji validitasnya. Justru dengan mengikuti manhaj-nya, kita dapat melakukan kontekstualisasi fiqh madzhab. Dalam posisi yang demikian, kita tidak terjebak dalam kemandegan fiqh, dan bermadzhab secara qauly bisa dilakukan secara selektif (kritis), dan sekaligus memberi peluang untuk melakukan ijtihad dengan mengikuti metodologi imam madzhab.

Bagaimanapun rumusan fiqh yang dikonstruksi ratusan tahun lalu jelas tidak memadai untuk menjawab semua persoalan yang terjadi saat ini. Di sinilah perlunya "fiqh baru" yang mengakomodir permasalahan-permasalahan baru yang muncul dalam masyarakat. Untuk itu kita harus kembali ke manhaj, yakni mengambil metodologi yang dipakai ulama dulu dan ushul fiqh serta qawầid fiqbiyyah. ${ }^{25}$

Produk fiqh nalar sosial-kontekstual di sini didasarkan pada dua sumber, yaitu dengan mengapresiasi kitab fiqh madzhab secara selektif (yang masih relevan) dengan mengkontekstualisannya, dan menggunakan qawâid fiqhiyyah. Sebagai pertimbangan dan acuan utama adalah maqâshid alsyarîah (kemaslahatan umat).

Dengan demikian dalam konteks fiqh NU, pengembangan fiqh sosial versi Sahal Mahfudh tidak serta merta menghilangkan peran khazanah klasik, dan kreativitas dalam pengembangan fiqh diharapkan tidak tercerabut dari akar tradisi orthodoxy. Persoalannya sekarang adalah bagaimana khazanah klasik itu disikapi. Untuk tujuan ini maka prinsip al-muhâfadhah 'alâ al-qadîm al-shâlih wa al-akhdžu bi al-jadîd al-aslah yang menjadi pegangan NU akan selalu menjadi panduan, atau dalam konsep ilmiah disebut sebagai prinsip continuity and change. Inilah jalan tengah yang ditempuh Kiai Sahal dalam melakukan istinbâth hukum

${ }^{25} \mathrm{KH}$. Sahal Mahfudh, Wawancara, tanggal 16 Juni 2005; Lihat juga Sahal Mahfudh, Wajah Baru Figh Pesantren (Jakarta: Citra Pustaka bersama Keluarga Mathali'ul Falah [KMF] Jakarta, 2004), 13. 
untuk keluar dari jebakan metodologi fiqh dan menghindari kejumudan pemikiran fiqh.

Sebagaimana diungkapkan Sahal Mahfudh, fiqh sosial memiliki lima ciri pokok yang menonjol: Pertama, interpretasi teks-teks fiqh secara kontekstual; Kedua, perubahan pola bermadzhab dari bermadzhab secara tekstual (madzhab qauly) ke bermadzhab secara metodologis (madzhab manhajy); Ketiga, verifikasi mendasar mana ajaran yang pokok (ushûl) dan mana ajaran yang cabang (furû); Keempat, fiqh dihadirkan sebagai etika sosial, bukan hukum positif negara; dan Kelima, pengenalan metodologi pemikiran filosofis, terutama dalam masalah budaya dan sosial. ${ }^{26}$ Kelima hal tersebut merupakan pengejawantahan dari upaya kontekstualisasi fiqh pola madzhab yang dipegangi oleh komunitas NU sehingga figh madzhab tidak ditinggalkan masyarakat.

Dalam mengapresiasi metode pengambilan hukum (istinbâth) Kiai Sahal menggunakan dua metode sekaligus. Pertama adalah menggunakan metode tekstual (madzhab qauly); dan kedua adalah metode kontekstual/metodologis (manhajy). ${ }^{27}$

\section{Nalar Fiqh Kritis-Emansipatoris.}

Nalar fiqh ini memahami konsep fiqh seperti pemahaman kelompok kedua, namun dalam hal mensikapi fiqh madzhab kelompok ini berbeda dari kelompok kedua. Fiqh madzhab dipandang sebagai produk ijtihad ulama masa lalu pada masanya yang memiliki konteks sosialnya sendiri, dan tentunya berbeda dari konteks sosialnya masyarakat kita sekarang ini. Untuk menjawab permasalahan-permasalahan baru dalam masyarakat sekarang, kita harus melakukan ijtihad sendiri, baik secara pribadi (fardi) atau secara kolektif (jama'?), bisa dengan memanfaatkan metodologi imam madzhab maupun dengan membuat kaidah-kaidah baru, sehingga solusi yang kita berikan benar-benar sesuai dengan konteks sekarang dan berdasarkan maqâshid al-syari'ah, yakni kemaslahatan umat.

${ }^{26}$ Ibid., xxxv.

${ }^{27} \mathrm{KH}$. Aziz Masyhuri, Masalab Keagamaan NU (Surabaya: PP RMI dan Dinamika Press, 1997), 364. 
Dalam melakukan ijtihad, kita bisa menempuh dua cara. Pertama, kita mengikuti manhaj (metodologi) yang telah ditempuh oleh para ulama mujtahid masa lalu. Dalam hal ini kita menggunakan pola bermadzhab secara manhajy, dengan menggunakan teori-teori hukum yang telah dihasilkan para mujtahid, yang tidak terbatas pada empat imam madzhab, tetapi bisa juga mengikuti manhaj (metodologi) dari imam madzhab selainnya. Manhaj tersebut kita transformasikan ke dalam konteks realitas kehidupan kita sekarang. Kedua, ijtihad yang kita lakukan benar-benar "ijtihad baru". Hal ini berarti bahwa kita tidak mengikuti metodologi imam madzhab, melainkan membuat rumusan-rumusan baru sebagai metodologi yang baru. Sebagai contoh adalah kita mengambil teori ijtihadnya (misalnya al-Maslabah al-Mursalah, al-Istibsâan, dan lainnya), lalu teori tersebut dikembangkan dengan kaidah-kaidah yang baru. Dengan kata lain, kita perlu melakukan rekonstruksi metodologi hukum. Dengan demikian, kita tidak terperangkap pada hegemoni pemikiran madzhab yang selama ini membelenggu ulama NU dan mengakibatkan statis dan tidak kreatif. Persoalan hukum yang muncul pada saat ini (juga dalam forum bahtsul masail) harus direspon dan dijawab dengan solusi yang benarbenar sesuai dengan konteks sosial dan kemaslahatan masyarakat modern sekarang ini. Darinya akan melahirkan fiqh (Islam) yang transformatif. 28

Untuk dapat mewujudkan idealitas fiqh sekarang ini, perlu dikedepankan dasar pemikiran tentang pentingnya fiqh (hukum Islam) ketika harus berdialektika dengan tantangan modernitas. Terlebih modernitas yang selalu dibarengi perubahan-perubahan yang cukup berarti. Perubahan-perubahan ini tentu harus disikapi sebagai suatu tantangan sekaligus ujian. Sejauh mana fiqh mampu menyikapi hal itu, dalam arti fiqh diupayakan selalu

${ }^{28}$ Istilah Islam transformatif ini dimunculkan dan disosialisasikan oleh Masdar F. Mas'udi, yang titik tolaknya pada problem kemanusiaan, bukan teks suci (teks-ide) sebagaimana Islam skriptualis yang tektualis dan formalistik, Islam ideologis yang apologetik-justifikatif dan sektarianis maupun Islam modernis yang terperangkap pada kemodernan dan kebenaran yang didefinisikan oleh orang lain. Lihat Masdar F. Mas'udi, "Paradigma dan Metodologi Islam Emansipatoris", Verdiansyah, Islam..., xvii-xviii. 
aktual dan relevan dengan perkembangan zaman. Pengambilan ketetapan hukum (istinbâth) tentunya memperhatikan perubahanperubahan konteksnya, sebagaimana diungkapkan dalam kaidah "taghayyur al-abkâm bi taghayyur al-azmân wa al-abwâl wa alamkinah".

Nalar Fiqh Kritis-Emansipatoris menurut Masdar berangkat dari pemikiran Islam Kritis. Kritis di sini bukan berarti bertanya terus atau ringkel, ${ }^{29}$ melainkan bertanya untuk memperoleh kejelasan sesuatu secara rasional. Sikap kritis ini mencakup dua elemen. Sikap kritis yang pertama adalah realitas material, yakni sebuah pemikiran yang mempertanyakan ideologi hegemonik yang bertolak pada kehidupan riil dan materiil atau mempertanyakan hegemoni bertolak pada realitas empirik. Sikap kritis yang kedua adalah visi transformatif yang memiliki komitmen pada perubahan struktur. ${ }^{30}$ Watak transformatif didefinisikan sebagai landasan bagi aksi pembebasan, di mana pembebasan ini tentu akan diterapkan pada problem kemanusiaan yang riil. Fiqh dengan demikian harus berpijak pada problem kemanusiaan, dan solusi yang diberikan harus mampu mentransformasikan nilai-nilai moral (etik) syari'ah yang akan membawa pada kemaslahatan manusia sebagaimana dipesankan oleh Islam. Dengan demikian, Fiqh Emansipatoris ini disebut dapat juga disebut sebagai Fiqh Transformatif, karena ia memiliki komitmen pada perubahan struktur figh dengan membebaskan diri dari keterpakuan kepada teks dan mengedepankan pada pesan esensial yang terkandung di dalamnya.

Produk fiqh nalar kritis-emansipatoris ini merupakan hasil ijtihad yang didasarkan pada maqâsid al-syarîah dan mengacu langsung kepada sumber aslinya, yaitu al-Qur'an-Hadis. Kitab fiqh madzhab dalam hal ini tidak dijadikan sumber referensi (marâji), karena dipandang sudah ketinggalan konteks masanya. Sebagai solusi yang harus dilakukan untuk menjawab persoalan fiqh sekarang adalah dengan melakukan ijtihad sendiri. Adapun caranya, bisa menggunakan pola manhaj imam madzhab dengan mengembangkannya, atau bahkan dengan membangun teori

\footnotetext{
${ }^{29}$ Ibid., xvi.

${ }^{30}$ Ibid., xvi.
} 
baru. Semua masalah fiqh (agama) harus mengacu pada maqâshid al-syarîab (kemaslahatan umat), yang terangkum dalam al-Kulliyat al-Khams, yaitu memelihara agama, jiwa, akal, harta, dan keturunan.

\section{Catatan Akhir}

Dengan melihat dinamika pemikiran fikih dalam Nahdlatul Ulama di atas yang melahirkan beragam corak nalar fikihnya, maka kajian ini menyumbangkan apa yang penulis sebut sebagai "teori dinamisme tradisi" yang mengacu pada teori "harmoni dialektisme-historis", di mana nilai-nilai tradisionalitas suatu komunitas (masyarakat) yang mememelihara al-turâts (warisan) akan tetap bertahan dan berkembang dinamis dalam suatu situasi yang selalu berubah (modern) apabila mampu: (1) merevitalisasi nilai-nilai tradisionalitas atas "warisan lama" (al-turats); (2) menyelaraskan nilai-nilai tradisi dan terbuka terhadap perubahan sebagai watak zaman dan masyarakat yang melingkupinya; (3) mendialogkan tradisi dan mengakomodir hasil peradaban (ilmu pengetahuan dan teknologi) masyarakat yang mengacu pada kaidah al-muhâfadhah 'alâ al-qadìm al-shâlih (konservasi) dan alakhdzu bi al-jadîd al-ashlah (inovasi), tanpa harus menghilangkan watak substansi tradisi.

Dua hal sebagai catatan kritis penulis dari kajian ini adalah bahwa (1) Sikap status quo yang berlebihan (statisme) dari penganut pola tradisionalitas justru kontra produktif bagi perkembangan peradaban, sehingga nilai-nilai tradisi dari altuirâts semakin dijauhi atau ditinggalkan oleh generasi mendatang karena tidak memenuhi harapan masyarakat. (2) Sikap pengingkaran terhadap tradisi (liberalisme) yang berlebihan dari penganut pola tradisi dan masyarakat yang menolak tradisi dengan menafikan nilai-nilai tradisi menyebabkan pada sikap "ketidakjujuran akademik", yakni pengingkaran terhadap sebuah 'karya' atau 'prestasi' dari peradaban masyarakat, padahal tradisi itu adalah sebuah realitas historis.

Oleh sebab itu, sikap yang bijaksana adalah bagaimana menerima eksistensi sebuah tradisi (pemikiran), namun juga tidak larut dalam totalisme dan fanatisme tradisi. Di sinilah 
sebenarnya arus kajian ini bermuara. Wa al-Lâh a lam bi alshawâb

\section{Daftar Pustaka}

Choirul Anam, Pertumbuban dan Perkembangan Nabdlatul Ulama (Sala: Jatayu Sala, 1985).

A. Qodri Azizy, Reformasi Bermazhab sebuah Ikbtiar Menuju Ijtihad Sesuai Saintifik-Modern (Jakarta: Teraju, 2003).

Imam Baihaqi (ed. ), Kontroversi Aswaja (Yogyakarta: LKiS, 1999). Wael B. Hallaq, Authority, Continuity, And Change in Islamic Law (Cambridge: Cambridge University Press, 2001). , Sejarah Teori Hukum Islam Pengantar Untuk Usul

Fiqh Mazhab Sunni, ter. E. Kusnadiningrat dan Abdul Haris bin Wahid (Jakarta: PT. Raja Grafindo Persada, 2001).

Muhammad Tholchah Hasan, Ahlussunnah wal Jamaah dalam Persepsi dan Tradisi NU (Jakarta: Lantabora Press, 2005).

Laode Ida, NU Muda Kaum Progresif dan Sekulerisme Baru (Jakarta: Penerbit Erlangga, 2004).

K. H. M. A. Sahal Mahfudh, Pesantren Mencari Makna (Jakarta: Pustaka Ciganjur, 1999). , Nuansa Fiqh Sosial (Yogyakarta: LKiS, 2004). ,Wajah Baru Figh Pesantren (Jakarta: Citra Pustaka bekerjasama dengan Keluarga Mathali'ul Falah (KMF) Jakarta, 2004).

Madar F. Mas'udi, "Meletakkan kembali Maslahat sebagai Acuan Syari'at”, dalam Ulumul Qur'an, Volume VI No. 3 (1995). "Paradigma dan Metodologi Islam

Emansipatoris", Very Verdiansyah, Islam Emansipatoris: Menafsir Agama Untuk Praksis Pembebasan (Jakarta: P3M (Perhimpunan Pengembangan Pesantren dan Masyarakat), 2004).

Menggagas Ulang Zakat sebagai Etika Pajak dan Belanja Negara untuk. Rakyat (Bandung: Mizan, 2005).

M. Imdadun Rahmat (ed. ), Kritik Nalar Fiqh NU: Transformasi Paradigma Bahtsul Masa’il (Jakarta: Lakpesdam, 2002). 
PWNU Jawa Timur, Wawasan Dasar Nabdlatul Ulama (Surabaya: Tim Perumus Konsep Sosialisasi Khittah Nahdlatul Ulama PWNU Jawa Timur, 1994).

Imam Ghazali Said dan A. Ma'ruf Asrori (peny. ), Abkam alFuqaha: Solusi Problematika Aktual Hukum Islam Keputusan Muktamar, Munas dan Kombes Nabdlatul Ulama (1926-1999 M) (Surabaya: Lajnah Ta'lif wan Nasyr (LTN) NU Jawa Timur bekerjasama dengan Penerbit Diantama Surabaya, 2005).

Achmad Shiddiq, Pedoman Berfikir Nabdlatul Ulama (Jember: Pergerakan Mahasiswa Islam Indonesia Cabang Jember, 1969). , Khittah Nabdliyyah (Jakarta: PBNU, t. t.). 